Thorax (1965), 20, 545.

\title{
Respiratory changes after open-heart surgery
}

\author{
J. B. M C CLENAHAN ${ }^{1}$, W. E. YOUNG ${ }^{2}$, A N D M. K. SYKES \\ From the Departments of Medicine and Anaesthesia, Postgradiate Medical School and Hammersmith Hospital, \\ London, $W .12$
}

Patients who have undergone cardiac surgery with the aid of extracorporeal circulation (E.C.C.) often exhibit varying degrees of respiratory embarrassment in the post-operative period. When severe, this pulmonary dysfunction is a prominent cause of morbidity and mortality. The general clinical picture and pathological changes in those who die have been well described (Muller, Littlefield, and Dammann, 1958; Dodrill, 1958; Baer and Osborn, 1960). The patient leaves the operating room in reasonably good condition, but within the first few hours dyspnoea, cyanosis, fever, and hypotension develop. If death ensues, it usually occurs within the first two days. No specific therapy is known. At necropsy the lungs are congested with focal zones of collapse and haemorrhage. The alveoli and bronchi are filled with red blood cells and proteinaceous oedema fluid.

Specific alterations in lung function result from these changes. Schramel, Cameron, Ziskind, A.dam, and Creech (1959) found a reduction in diffusing capacity for carbon monoxide, but similar findings were noted in patients and experimental animals who had undergone thoracotomy without total body perfusion. Preliminary studies in this Unit (Sykes, McCormick, Sandison, and Harrison, 1961) revealed that the arterial $\mathrm{CO}_{2}$ tension $\left(\mathrm{PaCO}_{2}\right)$ was seldom raised above $50 \mathrm{~mm}$. $\mathrm{Hg}$, but that arterial desaturation occurred almost invariably. The desaturation was usually present for three or four days after surgery, but in some cases it persisted for longer. In a few cases the desaturation was not completely relieved by the inhalation of $100 \%$ oxygen. In 1961 , Beer, Loeschcke, Schaudig, Pasini, Auberger, Ranz, and Borst reported that there was a reduction in diffusing capacity and an increase in right-to-left intrapulmonary shunting in both patients and animals who had been subjected to thoracotomy and total body perfusion. Howatt, Talner, Sloan, and DeMuth (1962) and Ellison, Yeh, Moretz, and Ellison (1963) noted a similar reduction in diffusing capacity, and Osborn, Popper, Kerth, and Gerbode

\footnotetext{
1 Supported by Fellowship, U.S. Public Health Service. Now Research Associate, Palo Alto Medical Research Foundation - Stanford University Health Service

2. S. S. McLaughlan Travelling Fellow. Now at St. Michael's Hospital, Toronto, Canada
}

(1962) reported increased arterial-alveolar carbon dioxide tension differences and arterial desaturation; they attributed this to patchy atelectasis.

This paper describes studies which were made on two groups of patients in an attempt to assess the effects of extracorporeal circulation on postoperative lung function.

\section{METHODS}

This series consists of 14 patients who were studied in Hammersmith Hospital in 1962 (Table I). The patients have been divided into two groups.

In group I were eight patients who underwent cardiac surgery with the aid of extracorporeal circulation. All but one included in this group appeared to have a normal post-operative course without any cardiological complication. The exception (A.C.) was progressing satisfactorily but died suddenly on the evening of the first post-operative day from a coronary artery occlusion.

In group II were six patients subjected to intrathoracic surgery without extracorporeal circulation. In this group one patient (M.H.) was operated upon with the aid of surface hypothermia, but all patients had normal lung function pre-operatively with the exception of M.D., a patient who had clinical evidence of chronic bronchitis and emphysema of moderate severity.

$\Lambda$ o patient in either group had any evidence of right-toleft intracardiac shunt on pre-operative examination or cardiac catheterization. Two patients in group I and three patients in group II had significant left-to-right intracardiac shunts before operation. There was no clinical evidence of a residual cardiac shunt in any patient after operation.

ANAESTHESIA AND PERfUSION Premedication consisted of a quinalbarbitone suppository, 3 to $4 \mathrm{mg}$. $/ \mathrm{kg}$., two hours before operation followed by a subcutaneous injection of pethidine, 2 to $3 \mathrm{mg}$. $/ \mathrm{kg}$., and promethazine, 1.0 to $1.5 \mathrm{mg} . / \mathrm{kg}$., one hour before operation. Anaesthesia was induced with thiopentone, 50 to $250 \mathrm{mg}$., and muscular relaxation was obtained with $\mathbf{D}$-tubocurarine, 15 to $30 \mathrm{mg}$. Respirations were controlled using a mixture of nitrous oxide $70 \%$ and oxygen $30 \%$ from a nonrebreathing system on a mechanical ventilator, except during the period of total cardiopulmonary bypass, when the lungs were held inflated with a mixture of helium, or nitrogen, and oxygen. Small doses of pethidine, 10 to 
TABLE I

GROUP I. PATIENTS STUDIED

\begin{tabular}{|c|c|c|c|c|c|c|c|c|c|c|c|}
\hline Patient & Sex & Age & $\begin{array}{c}\text { Weight } \\
\text { (kg.) }\end{array}$ & $\begin{array}{c}\text { Height } \\
\text { (cm.) }\end{array}$ & $\begin{array}{l}\text { Surface } \\
\text { Area } \\
\left(\mathbf{m} .^{2}\right)\end{array}$ & Diagnosis & Operation & $\begin{array}{c}\text { Per- } \\
\text { fusion } \\
\text { Time } \\
\text { (min.) }\end{array}$ & $\begin{array}{l}\text { Total } \\
\text { Bypass } \\
\text { (min.) }\end{array}$ & $\begin{array}{l}\text { Lowest } \\
\text { Temp. } \\
\text { Recorded } \\
\text { ( }{ }^{\circ} \text { C. oeso- } \\
\text { phageal) }\end{array}$ & $\begin{array}{l}\text { Pulmonary } \\
\text { Complications }\end{array}$ \\
\hline V.P. & $\mathbf{F}$ & 29 & $42 \cdot 5$ & 153 & $1 \cdot 37$ & $\begin{array}{l}\text { Atrial septal } \\
\text { defect }\end{array}$ & Closure & 48 & 44 & 30 & $\begin{array}{l}\text { ? Pulmonary artery } \\
\text { thrombosis on second } \\
\text { post-op. day }\end{array}$ \\
\hline E.W. & $\mathbf{M}$ & 32 & $64 \cdot 0$ & 168 & $1 \cdot 75$ & $\begin{array}{l}\text { Aortic } \\
\text { incompetence }\end{array}$ & $\begin{array}{c}\text { Aortic valve } \\
\text { replacement }\end{array}$ & - & - & - & Patchy collapse and con- \\
\hline H.A. & $\mathbf{M}$ & 25 & $56 \cdot 5$ & 178 & $1 \cdot 70$ & $\begin{array}{l}\text { Aortic } \\
\text { incompetence }\end{array}$ & $\begin{array}{l}\text { Aortic valve } \\
\text { replacement }\end{array}$ & 207 & 220 & 22 & $\begin{array}{l}\text { Some left lower lobe col- } \\
\text { lapse }\end{array}$ \\
\hline T.C. & $\mathbf{M}$ & 19 & $51 \cdot 8$ & 159 & $1 \cdot 51$ & $\begin{array}{l}\text { Obstructive } \\
\text { cardiomyopathy }\end{array}$ & $\begin{array}{l}\text { Infundibular } \\
\text { resection }\end{array}$ & 69 & 59 & 24 & $\begin{array}{l}\text { Some left lower lobe col- } \\
\text { lapse }\end{array}$ \\
\hline S.R. & $\mathbf{F}$ & 25 & $64 \cdot 5$ & 157 & $1 \cdot 67$ & $\begin{array}{l}\text { Obstructive } \\
\text { cardiomyopathy }\end{array}$ & $\begin{array}{l}\text { Infundibular } \\
\text { resection }\end{array}$ & 67 & 50 & 24 & $\begin{array}{l}\text { Slight left lower lobe col- } \\
\text { lapse }\end{array}$ \\
\hline J.B. & $\mathbf{F}$ & 36 & $45 \cdot 0$ & 156 & $1 \cdot 42$ & $\begin{array}{l}\text { Obstructive } \\
\text { cardiomyopathy }\end{array}$ & $\begin{array}{l}\text { Infundibular } \\
\text { resection }\end{array}$ & 76 & 60 & 26 & Some collapse both bases \\
\hline A.C. & $\mathbf{M}$ & 33 & $58 \cdot 5$ & 171 & 1.62 & $\begin{array}{l}\text { Aortic } \\
\text { incompetence }\end{array}$ & $\begin{array}{l}\text { Aortic valve } \\
\text { replacement }\end{array}$ & 240 & 222 & 23 & Nil \\
\hline P.H. R. & $\mathbf{M}$ & 16 & 56.0 & 173 & 1.68 & $\begin{array}{l}\text { Ventricular } \\
\text { septal defect }\end{array}$ & Closure & 83 & 63 & 24 & Nil \\
\hline
\end{tabular}

GROUP II. CONTROLS

\begin{tabular}{|c|c|c|c|c|c|c|c|c|}
\hline Patient & Sex & Age & $\begin{array}{l}\text { Weight } \\
\text { (kg.) }\end{array}$ & $\begin{array}{l}\text { Height } \\
\text { (cm.) }\end{array}$ & $\begin{array}{l}\text { Surface } \\
\text { Area } \\
\left(\mathrm{m} .^{2}\right)\end{array}$ & Diagnosis & Operation & Pulmonary Complications \\
\hline $\begin{array}{l}\text { R.P. } \\
\text { R.McN. }\end{array}$ & $\begin{array}{l}\mathbf{M} \\
\mathbf{M}\end{array}$ & $\begin{array}{l}24 \\
16\end{array}$ & $\begin{array}{l}66 \cdot 8 \\
61 \cdot 0\end{array}$ & 184 & $1 \cdot 86$ & $\begin{array}{l}\text { Coarctation of aorta } \\
\text { Patent ductus arteriosus }\end{array}$ & $\begin{array}{l}\text { Resection and graft } \\
\text { Ligation }\end{array}$ & $\begin{array}{l}\text { Nil } \\
\text { Left haemothorax with some } \\
\text { left lower lobe collapse }\end{array}$ \\
\hline $\begin{array}{l}\text { M.H. } \\
\text { J.L. } \\
\text { P.H.-R. }\end{array}$ & $\begin{array}{l}\mathbf{M} \\
\mathbf{M}\end{array}$ & $\begin{array}{l}15 \\
22 \\
16\end{array}$ & $\begin{array}{l}68 \\
74 \cdot 2 \\
56 \cdot 0\end{array}$ & $\frac{178}{173}$ & $\frac{1.85}{1 \cdot 68}$ & $\begin{array}{l}\text { Atrial septal defect } \\
\text { Coarctation of aorta } \\
\text { Patent ductus arteriosus } \\
\text { and ventricular septal } \\
\text { defect }\end{array}$ & $\begin{array}{l}\text { Closure } \\
\text { Resection } \\
\text { Closure of patent ductus } \\
\text { arteriosus }\end{array}$ & $\begin{array}{l}\text { Slight collapse left base } \\
\text { Small left pneumothorax } \\
\text { Nil }\end{array}$ \\
\hline M.D. & $\mathbf{M}$ & 40 & $58 \cdot 2$ & - & - & Granuloma of lung & $\begin{array}{l}\text { Total resection of granuloma } \\
\text { of lung }\end{array}$ & $\begin{array}{l}\text { No clinical or radiologica } 1 \\
\text { change }\end{array}$ \\
\hline
\end{tabular}

$20 \mathrm{mg}$., were used to supplement the anaesthesia and additional doses of pethidine and $\mathbf{D}$-tubocurarine were given to maintain anaesthesia during the period of perfusion. A Melrose-N.E.P. pump-oxygenator was used for bypass, and blood flow rates were maintained at 2.41 . $/ \mathrm{min} . / \mathrm{m}^{2}$ body surface area. Flow rates were reduced slightly when hypothermia was utilized as an adjunct to the perfusion technique (El Sayed and Melrose, 1962). The lowest temperatures recorded (Table I) were used to achieve hypothermic arrest of the heart. During the rest of the perfusion the body temperature was maintained at $30^{\circ} \mathrm{C}$. or above. Rheomacrodex, a lowmolecular-weight dextran, $1,100 \mathrm{ml}$., was added to $4,000 \mathrm{ml}$. of priming blood. At the end of bypass the lungs were inflated for a short period with positive pressures of up to $30 \mathrm{~cm} . \mathrm{H}_{2} \mathrm{O}$ in an attempt to re-expand any atelectatic areas. At the conclusion of operation residual curarization was reversed with atropine, $1.2 \mathrm{mg}$., and neostigmine, $2.5 \mathrm{mg}$., in divided doses. Artificial ventilation was maintained until spontaneous ventilation was adequate. A similar anaesthetic technique was used for patients not subjected to total body perfusion. Oxygen was administered during transfer to the recovery ward. Patients in group I were then nursed in an oxygen tent for three days and patients in group II for 24 hours.

Patients were studied one or two days before operation, two to three hours after return to the recovery ward, on the first and second post-operative days, and, in a few음 cases, several weeks after the operation. All measure- $\tilde{x}$ ments were made with the patient in the supine position 0 with the head resting on one pillow. The patients 3 . breathed through a mouthpiece connected to a low- $\hat{\theta}$ resistance non-rebreathing valve. The dead space of the $₹$ valve and mouthpiece was $80 \mathrm{ml}$. Expired gas was collected in a Douglas bag, the volume being sub- $\mathrm{J}$ sequently measured on a calibrated dry test gas meter. 1 긍 Studies were made with the subjects breathing air, $100 \%$. oxygen, and, in some cases, $35 \%$ oxygen. After the N desired gas mixture had been respired for eight to 10 . minutes, the bag was washed out twice with expired gas $N$ and emptied again. Expired gas was then collected for a period of five to six minutes. At the same time an arterial $\sigma$ blood sample, from a needle or catheter in the brachial 2 or radial artery, was slowly withdrawn into an oiled, $\stackrel{\varrho}{\subset}$ heparinized syringe which was capped and stored in iced water. Immediately after the period of collection, four samples of mixed expired gas from the Douglas $T$ bag were flushed through a 100-ml. oiled syringe, the fifth sample being retained for analysis. Finally, the baro- $\bigcirc$ metric pressure, room temperature, and patient's temperature were recorded.

${ }^{1}$ Type C.D.1, Parkinson-Cowan Ltd., London 
BLOOD-GAS ANALYSIS The oxygen and carbon dioxide tensions of both expired gas and arterial blood were determined on the combined electrode system described by Severinghaus and Bradley (1958).2 The oxygen electrode was calibrated using pure nitrogen, air, and a $95 \% \quad \mathrm{O}_{2}: 5 \% \quad \mathrm{CO}_{2}$ mixture. The carbon dioxide electrode was standardized using $3 \% \mathrm{CO}_{2}$ and $6 \% \mathrm{CO}_{2}$ in oxygen. All $\mathrm{CO}_{2}$ mixtures were analysed on a standard Haldane gas analysis apparatus, calibrated by mercury displacement and checked by the analysis of total absorbable gas in air. The electrodes were maintained at a constant temperature of $37^{\circ} \mathrm{C} . \pm 0 \cdot 1^{\circ} \mathrm{C}$.

SOURCES OF ERROR

(a) Expired gas volume The gas meter was calibrated against a spirometer which was in turn calibrated by water displacement. Suitable temperature corrections were made. When random volumes of gas were passed through the spirometer at rates approximating to those used in the studies, the mean error of the gas meter was $-32.6 \mathrm{ml}$./litre. The S.D. of the difference between the known and observed was $6.45 \mathrm{ml}$. and the S.E. of the mean difference equalled $1 \cdot 42$. Since this error was small no correction was applied to the volumes measured.

(b) Oxygen The accuracy of the oxygen tension determinations on gases was assessed initially and checked throughout the period of study by measuring the oxygen tension of gases of known oxygen concentration. Gases were analysed on a standard Haldane gas analysis apparatus and the $\mathrm{Po}_{2}$ was calculated directly from the oxygen percentage, or, in the case of the $5 \% \mathrm{CO}_{2}: 95 \% \mathrm{O}_{2}$ mixtures, by subtracting the $\% \mathrm{CO}_{2}$ from $100 \%$. In 109 determinations on 8.8 to $21.0 \% \mathrm{O}_{2}$ in $\mathrm{N}_{2}$ the mean error of the electrode was $+0.024 \mathrm{~mm}$. Hg (S.D. $=$ $1.04 \mathrm{~mm}$. Hg; S.E. of mean $=0.11$ ).

Three factors reduced the degree of accuracy obtained in these studies. First, blood samples from a tonometer gave lower readings on the electrode than did the gas with which they were equilibrated. This 'blood-gas' ratio varied from day to day and was determined at the time of each study using the patient's blood in the majority of instances. Correction factors varying from 100 to $112 \%$ were applied to the readings obtained. Second, the electrode was frequently alinear over the 300 to $700 \mathrm{~mm}$. Hg range of oxygen tensions. The electrode was checked daily by measuring the $\mathrm{Po}_{2}$ of a range of known gas mixtures, and appropriate corrections were applied to the readings obtained. The third source of error was the rapid fall of $\mathrm{Po}_{2}$ in blood having a high initial oxygen tension. The rate of fall varied widely and was dependent on the initial $\mathrm{O}_{2}$ tension and the duration and temperature of storage. $A$ number of experiments were performed to determine this rate of fall, and a correction factor was applied to all measurements made at high oxygen tensions. Although arterial oxygen tensions were always determined within 10 minutes of sampling, the errors introduced by the determination and application of these correction factors probably reduced the

2 Yellow [Springs Instrument Company, Yellow Springs, Ohio, U.S.A. accuracy of the electrode to $\pm 30 \mathrm{~mm}$. $\mathrm{Hg}$ at $\mathrm{O}_{2}$ tensions above $400 \mathrm{~mm}$. Hg. Such an error would limit the accuracy of shunt determination to approximately $\pm 3 \%$ at high oxygen tensions.

(c) Carbon dioxide $\mathbf{P C O}_{2}$ was determined on a standard Severinghaus electrode using a 1/1,000-in. teflon membrane and $0.01 \mathrm{M} \mathrm{NaHCO}$ and $0.10 \mathrm{M} \mathrm{KCl}$ bufler. The output was read on a Vibron electrometer, model 33B, ${ }^{3}$ as a difference in millivolts from a standard $\mathrm{CO}_{2}-\mathrm{O}_{2}$ mixture. The $\% \mathrm{CO}_{2}$ was then read from a sem i-logarithmic plot of concentration versus millivolts. The accuracy of this system was assessed initially and throughout the course of the studies with known $\mathrm{CO}_{2}-\mathrm{O}_{2}$ gas mixtures and with blood equilibrated in a tonometer with gas of a known $\mathrm{PCO}_{2}$. In 32 determinations on mixtures containing 2.64 to $9.59 \% \mathrm{CO}_{2}$ in $\mathrm{O}_{2}$, the mean difference between the electrode reading and the known concentration of the standard gas was $+0 . \mathrm{C} 44 \mathrm{~mm}$. $\mathrm{Hg}$ (S.D. 0.45 mm. Hg). With 28 samples of equilibrated blood the mean error was $+0.28 \mathrm{~mm}$. $\mathrm{Hg}$ (S.D. $0.65 \mathrm{~mm}$. Hg). Eighteen duplicate determinations were carried out during the course of the studies: these all agreed within $0.5 \mathrm{~mm}$. $\mathrm{Hg}$.

The $\mathrm{PCO}_{2}$ of blood samples stored in iced water was found to be stable within the limits of the method for up to two hours. Blood gas tensions were corrected to body temperature using the nomograms of Bradley, Stupfel, and Severinghaus (1956).

Blood $\mathrm{pH}$ measurements were made using an Astrup macro-electrode system (Astrup and Schrøder, 1956), and a Radiometer PHM4 pH meter.4

Calculations Physiological dead space $\left(\dot{V}_{D}\right)$ and alveolar oxygen tension $\left(\mathrm{PAO}_{2}\right)$ were calculated from the standard equations (Comroe, Forster, Dubois, Briscoe, and Carlsen, 1962a). The physiological right-to-left shunt or venous admixture effect was calculated from the values obtained when breathing air using the formula

$$
\frac{\dot{Q}_{\mathrm{s}}}{\dot{\mathrm{Q}}_{\mathrm{t}}}=\frac{\mathrm{Ca}_{\mathrm{O}_{2}}-\mathrm{Cc}^{\prime} \mathrm{O}_{2}}{\mathrm{CV}_{\mathrm{O}_{2}}}-\frac{\mathrm{Cc}_{\mathrm{O}_{2}}^{\prime}}{}
$$

where $\dot{Q}_{\mathbf{s}} / \dot{Q}_{\mathbf{t}}=$ shunt expressed as \% of cardiac output, $\mathrm{CaO}_{2}=$ arterial oxygen content (vol. $\left.\%\right), \mathrm{Cc}^{\prime} \mathrm{O}_{2}=$ endpulmonary capillary oxygen content (vol. $\%$ ), and $\mathrm{C} \mathrm{vo}_{2}=$ mixed venous oxygen content $(\mathrm{vol} . \%$ )

Blood with an oxygen tension of $170 \mathrm{~mm} . \mathrm{Hg}$ was considered fully saturated (Haab, Piiper, and Rahn, 1960). The solubility coefficient for dissolved oxygen was taken as 0.003 vol. $\% \mathrm{~mm}$. $\mathrm{Hg}$ (Finley, I enfant, Haab, Piiper, and Rahn, 1960). Oxygen capacity was assumed to be 20 vol. $\%$ unless the packed cell volume was below $40 \%$ or above $50 \%$. In these circumstances the capacity (vol.\%) was taken as $\mathrm{Hb}(\mathrm{g}) \times$.1.34 (Comroe, Forster, Dubois, Briscoe, and Carlsen, 1962b).

When calculating $\mathrm{CaO}_{2}$ the arterial oxygen tensicn $\left(\mathrm{PaO}_{2}\right)$ and $p \mathrm{H}$ were used to read the percentage oxygen saturation $\left(\mathrm{SaO}_{2}\right)$ from the dissociation curve.

Then $\mathrm{CaO}_{2}=\left(\right.$ capacity $\left.\times\left[\mathrm{SaO}_{2} / 100\right]\right)+\left(\mathrm{PaO}_{2} \times\right.$ 0.003).

${ }^{3}$ Electronic Instruments Ltd., Richmond, Surrey, England

4 Radiometer Ltd., Copenhagen, Denmark 


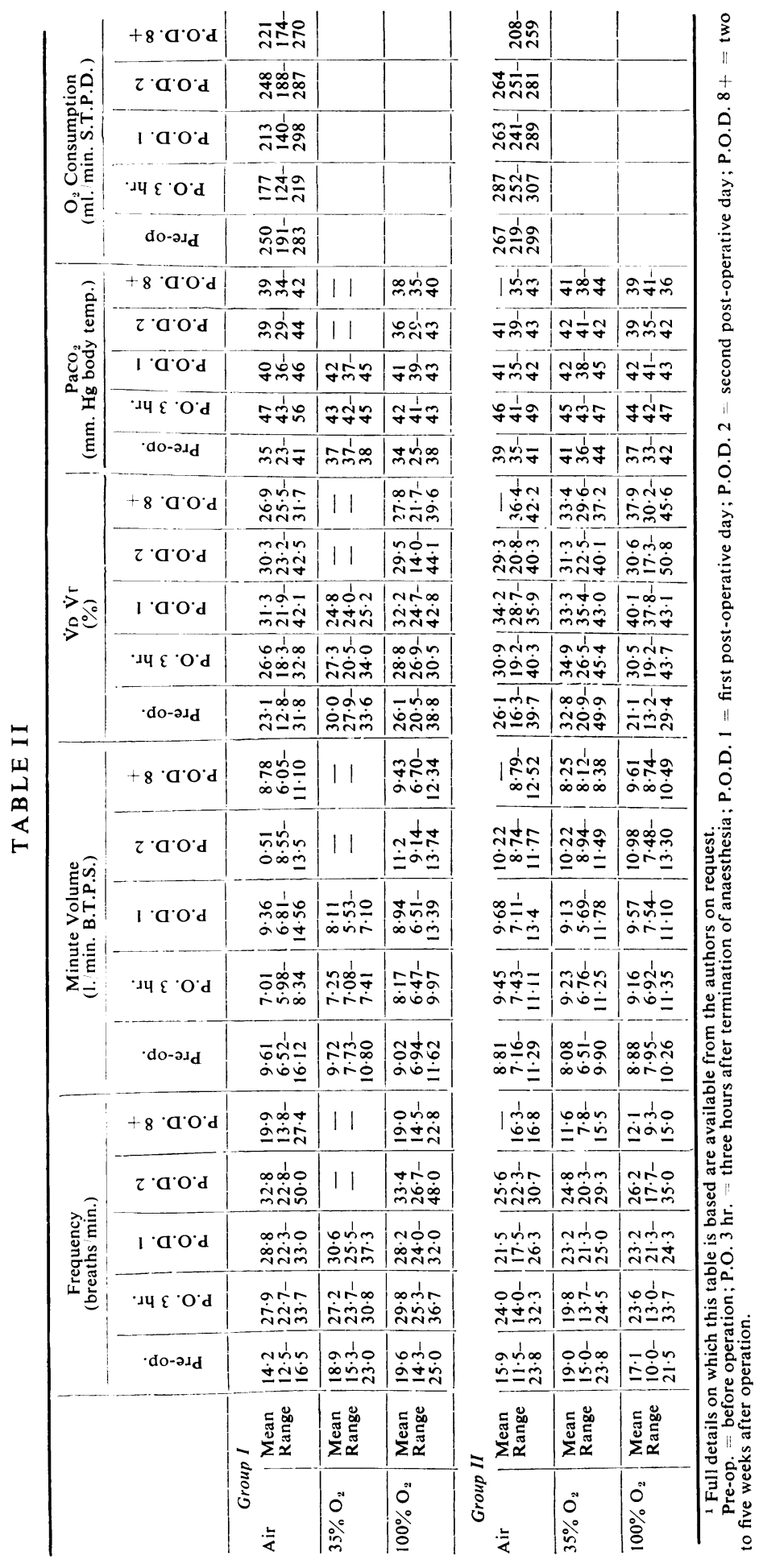


When calculating $\mathrm{Cc}^{\prime} \mathrm{O}_{2}$ the same formula was applied, but it was assumed that the end-pulmonary capillary blood had the same $\mathbf{P O}_{2}$ as the calculated mean $\mathbf{P A O}_{2}$. Thus any A-c' oxygen tension gradient was included in the calculated venous admixture effect.

$\mathrm{C} \overline{\mathrm{v}} \mathrm{O}_{2}$ was assumed to equal $\mathrm{CaO}_{2}-5$ vol. $\%$ unless otherwise stated. In those patients in whom intracardiac left-to-right shunts were demonstrated at pre-operative cardiac catheterization, the $\mathrm{A}-\mathrm{V}$ difference found at that time was utilized when calculating the pre-operative value for $\dot{Q}_{\mathrm{s}} / \dot{\mathbf{Q}}_{\mathrm{t}}$.

For calculation of true (anatomical) shunt the values obtained when breathing $100 \%$ oxygen were substituted in the shunt equation quoted above. Since arterial blood is fully saturated at these levels the difference in content must be calculated from the oxygen dissolved in plasma. If $\left(\mathrm{A}-\mathrm{a} \mathrm{Po}_{2}\right)$ represents the alveolar-arterial oxygen tension diference, the shunt equation then simplifies to:

$$
\dot{\mathrm{Q}}_{\mathrm{s}}=\frac{\left(\mathrm{A}-\mathrm{a} \mathrm{P}_{\mathrm{O}_{2}}\right) \times 0.003}{\left[\left(\mathrm{~A}-\mathrm{a} \mathrm{P}_{\mathrm{O}_{2}}\right) \times 0.003\right]+5}
$$

\section{RESULTS}

VENTILATION (TABLE II; FIG. I)

Frequency of respiration In group I, the frequency of respiration (f) increased immediately after operation and reached a peak on the second post-operative day. In a number of cases the respiratory rate was still raised one week after operation. In group II, similar changes were seen but the increase in frequency was less marked. The respiratory rate was normal after one week.

Tidal volume In group I, the tidal volume $\left(\dot{\mathrm{V}}_{\mathrm{T}}\right)$ fell dramatically immediately after operation and was still reduced several weeks after operation. In group II, the fall in tidal volume was much less marked.

Minute volume In group I, there was a reduction in minute volume $\left(\dot{V}_{E}\right)$ three hours after operation, but this then increased to reach a maximum on the second post-operative day. In group II, similar findings were noted.

Physiological dead space In group I, the physiological dead space $\left(\dot{V}_{D}\right)$ fell to half the pre-operative value immediately after operation and then gradually returned to normal values. The dead space/tidal volume $\left(\dot{V}_{D} / \dot{V}_{T}\right)$ ratio increased slightly after operation and remained at the upper limits of normal for several weeks.

In group II, the reduction in physiological dead space was less marked and the $\dot{V}_{D} / \dot{V}_{T}$ ratio was

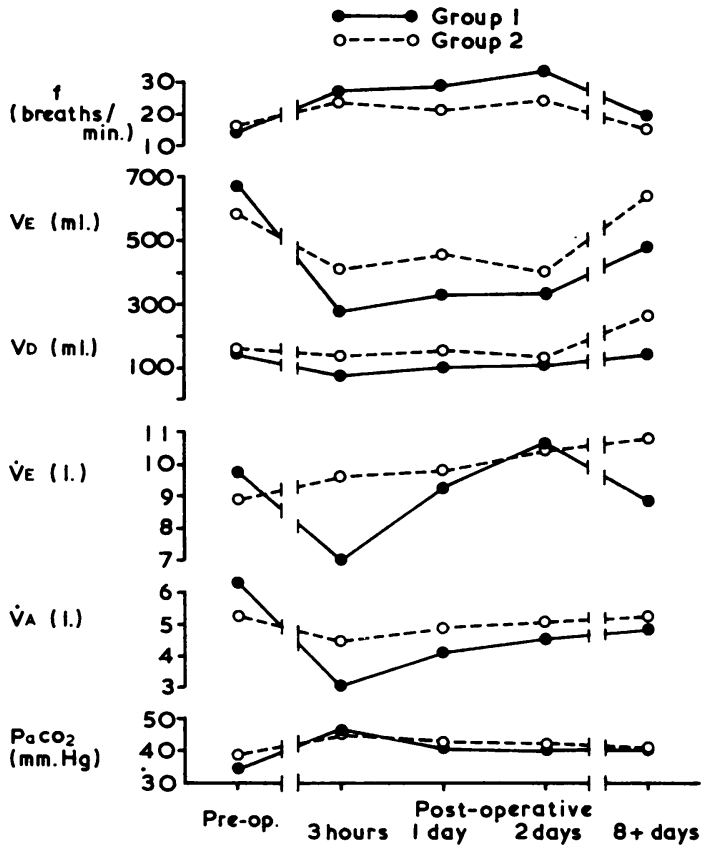

FIG. 1. Ventilatory changes. Abscissa: measurements taken before operation ('Pre-op'), 3 hours after the end of anaesthesia (' 3 hours post-op'), on the first and second post-operative days, and one to three weeks after operation $($ ' $8+$ days').

slightly increased after operation. Patient M.D. had a raised $\dot{V}_{D} / \dot{V}_{T}$ ratio before operation which remained unaltered during the post-operative period.

Alveolar ventilation In group I, the alveolar ventilation was reduced immediately after operation and did not return to normal until the second postoperative day. In group II, there was a reduction in alveolar ventilation for several hours after operation, but values were normal by the first or second post-opərative day.

\section{OXYGEN TRANSFER (TABLES III AND IV)}

Pre-operative studies Pre-operatively, the alveolararterial oxygen tension difference (A-a $\left.\mathrm{Po}_{2}\right)$ while breathing air was less than $10 \mathrm{~mm}$. $\mathrm{Hg}$ in all but two patients. Patient J.B. (group I), a woman with obstructive cardiomyopathy, had an A-a $\mathbf{P o}_{2}$ of $17 \mathrm{~mm}$. Hg. Patient M.D. (group II), an older man with known chronic lung disease, had an $\mathrm{A}-\mathrm{a} \mathrm{Po}_{2}$ of $40 \mathrm{~mm}$. Hg. For this reason all values for patient M.D. were excluded from the group means. When breathing $100 \%$ oxygen the $\mathrm{A}-\mathrm{a} \mathrm{Po}_{2}$ in group I ranged from 42 to $136 \mathrm{~mm}$. $\mathrm{Hg}$ with a mean of 
TABLE III

SUMMARY OF RESULTS : A-a $\mathrm{PO}_{2}(\mathrm{~mm} . \mathrm{Hg})$

\begin{tabular}{|c|c|c|c|c|c|c|c|c|c|c|c|c|c|c|c|}
\hline & \multicolumn{15}{|c|}{ Sample Time } \\
\hline & \multicolumn{3}{|c|}{ Pre-cperative } & \multicolumn{3}{|c|}{3 Hours Post-op. } & \multicolumn{3}{|c|}{ P.O.D. 1} & \multicolumn{3}{|c|}{ P.O.D. 2} & \multicolumn{3}{|c|}{ Weeks Post-op. } \\
\hline & Air & $\begin{array}{c}35 \% \\
\mathrm{O}_{2}\end{array}$ & $\begin{array}{c}100 \% \\
O_{2}\end{array}$ & Air & $\begin{array}{c}35 \% \\
\mathrm{O}_{2}\end{array}$ & $\begin{array}{c}100 \% \\
\mathrm{O}_{2}\end{array}$ & Air & $\begin{array}{c}35 \% \\
\mathrm{O}_{2}\end{array}$ & $\begin{array}{c}100 \% \\
\mathrm{O}_{2}\end{array}$ & Air & $\begin{array}{c}35 \% \\
\mathrm{O}_{2} \\
\end{array}$ & $\begin{array}{c}100 \% \\
0\end{array}$ & Air & $\begin{array}{c}35 \% \\
\mathrm{O}_{2}\end{array}$ & $\begin{array}{c}100^{\circ} \\
\mathrm{O}_{2}\end{array}$ \\
\hline \multicolumn{16}{|c|}{ Gicıp I: Extracoiporea I circulation } \\
\hline $\begin{array}{l}\text { Mean } \\
\text { Range }\end{array}$ & $\begin{array}{c}8 \\
4-17 \\
\end{array}$ & $\begin{array}{c}34 \\
31-36 \\
\end{array}$ & $\begin{array}{c}79 \\
42-136 \\
\end{array}$ & $\begin{array}{c}33 \\
12-51 \\
\end{array}$ & $76-128$ & $\begin{array}{r}236 \\
66-442 \\
\end{array}$ & $\begin{array}{c}36 \\
8-46\end{array}$ & $\begin{array}{c}101 \\
83-115 \\
\end{array}$ & $\begin{array}{c}326 \\
121-465\end{array}$ & $\begin{array}{l}40 \\
7-77\end{array}$ & - & $\begin{array}{c}357 \\
207-611\end{array}$ & $\begin{array}{c}7 \\
0-22\end{array}$ & - & $76-153$ \\
\hline \multicolumn{16}{|c|}{ Group II: No extracorporeal circulation } \\
\hline $\begin{array}{l}\text { Mean }{ }^{1} \\
\text { Range }\end{array}$ & $\begin{array}{c}0 \\
(40) \\
0\end{array}$ & $\begin{array}{c}11 \\
(115) \\
9-17\end{array}$ & $\stackrel{45}{\left(-\frac{-}{17-65}\right.}$ & $\begin{array}{l}14 \\
(41) \\
6-23\end{array}$ & $\begin{array}{c}24 \\
(100) \\
16-32\end{array}$ & $\begin{array}{c}111 \\
(149) \\
33-211\end{array}$ & $\begin{array}{c}11 \\
(52) \\
10-12\end{array}$ & $\begin{array}{c}\overline{(126)} \\
33-44\end{array}$ & $\begin{array}{l}118 \\
(255) \\
62-157\end{array}$ & $\begin{array}{c}18 \\
(40) \\
12-25\end{array}$ & $\begin{array}{c}(\overline{128}) \\
32\end{array}$ & $\begin{array}{l}138 \\
(247) \\
65-212\end{array}$ & $\begin{array}{c}\overline{45}) \\
11\end{array}$ & $\begin{array}{c}\overline{(85)} \\
29\end{array}$ & $\begin{array}{c}\overline{(161)} \\
64\end{array}$ \\
\hline
\end{tabular}

1 Values for patient M.D. given in brackets. These figures are excluded from the group means.
3 hours post-op. $=3$ hours after termination of anaesthesia; P.O.D. $1=$ first post-operative day; P.O.D. $2=$ second post-operative day.

TABLE IV

SUMMARY OF RESULTS: VENOUS ADMIXTURE AND TRUE SHUNTS

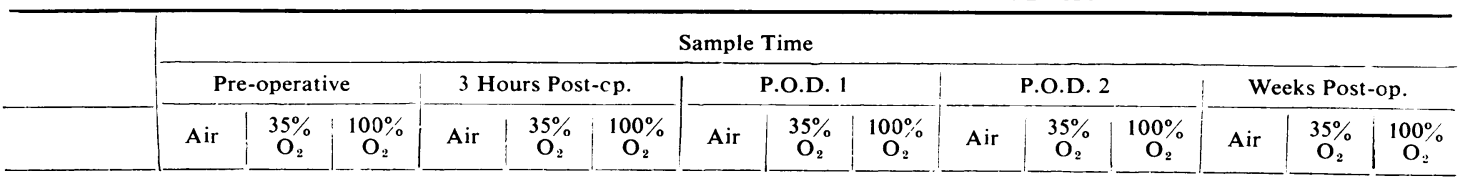

Group I: Extracorporeal circulation

\begin{tabular}{|c|c|c|c|c|c|c|c|c|c|c|c|c|c|c|c|c|}
\hline $\begin{array}{l}\text { Mean } \\
\text { Range }\end{array}$ & . & $\begin{array}{l}2 \cdot 8 \\
1 \cdot 8 \\
4 \cdot 4\end{array}$ & $\begin{array}{l}1 \cdot 9 \\
1 \cdot 8- \\
2 \cdot 0\end{array}$ & $\begin{array}{l}4 \cdot 4 \\
2 \cdot 2- \\
7 \cdot 5\end{array}$ & $\begin{array}{c}21 \cdot 4 \\
8 \cdot 9- \\
33 \cdot 0\end{array}$ & $\begin{array}{l}\overline{10 \cdot 0-} \\
26 \cdot 0\end{array}$ & $\begin{array}{c}12 \cdot 0 \\
3 \cdot 8 \\
21 \cdot 0\end{array}$ & $\begin{array}{c}21 \cdot 1 \\
3 \cdot 1- \\
31 \cdot 0\end{array}$ & $\begin{array}{l}16 \cdot 6 \\
10 \cdot 0- \\
23 \cdot 0\end{array}$ & $\begin{array}{c}16 \cdot 2 \\
6 \cdot 7- \\
22 \cdot 0\end{array}$ & $\begin{array}{c}23 \cdot 8 \\
3 \cdot 8- \\
46 \cdot 0\end{array}$ & Z & $\begin{array}{l}19 \cdot 3 \\
11 \cdot 0- \\
39 \cdot 0\end{array}$ & $\begin{array}{c}3 \cdot 6 \\
0- \\
12 \cdot 0\end{array}$ & 二 & $\begin{array}{l}\overline{4 \cdot 3} \\
8 \cdot 4\end{array}$ \\
\hline
\end{tabular}

Group JI : No extracorporeai circulation

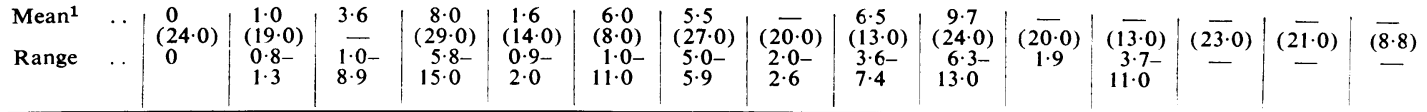

${ }^{1}$ Values for patient M.D. given in brackets. These figures are excluded frcm the group means.

3 hours post-op. $=3$ hours after termination of anaesthesia; P.O.D. $1=$ first post-operative day; P.O.D. $2=$ second post-operative day.

$79 \mathrm{~mm} . \mathrm{Hg}$, whereas the $\mathrm{A}-\mathrm{a} \mathrm{PO}_{2}$ in group II ranged from 17 to $65 \mathrm{~mm}$. F.g with a mean of $45 \mathrm{~mm}$. $\mathrm{Hg}$. On a $35 \%$ oxygen mixture the $\mathrm{A}$-a $\mathrm{Fo}_{2}$ was 31 to $36 \mathrm{~mm}$. $\mathrm{Hg}$ and 9 to $17 \mathrm{~mm}$. $\mathrm{Fg}$ for groups I and II respectively.

The mean calculated physiological shunts for the two groups breathing air were $2 \cdot 8 \%$ for group I and $0 \%$ for group II.

Post-operative studies A.ll paticnts but ore who were operated upon under extracorporeal circulation developed large alveolar-arterial oxygen tension differences during the 48 hours after surgery. These were usually evident within three hours after return to the recovery ward. The abnormal $\mathrm{A} \cdot \mathrm{a} \mathrm{Po}_{2}$ was most marked on the morning after operation and of similar magnitude on the next day. In group $I$, the $\mathrm{A}$-a $\mathrm{Po}_{2}$ varied from 8 to $77 \mathrm{~mm}$. $\mathrm{Hg}$ when breathing air, and on $100 \%$ oxygen differences ranged from 66 to $611 \mathrm{~mm}$. Hg. On three occasions it was deemed unwise to evaluate the patient on air.

In group $\mathrm{II}$, the maximum $\mathrm{A}-\mathrm{a} \mathrm{FO}_{2}$ on air was
$52 \mathrm{~mm}$. $\mathrm{Hg}$ in patient M.D. who had an abnormal value $(40 \mathrm{~mm} . \mathrm{Hg})$ in his pre-operative study. In the other five patients the $\mathrm{A}-\mathrm{a} \mathrm{Fo}_{2}$ ranged from 6 to $25 \mathrm{~mm}$. Hg. Ereathing $100 \%$ oxygen, the maximum $\mathrm{A}-\mathrm{a} \mathrm{Po}_{2}$ in the non-perfusion group was $212 \mathrm{~mm} . \mathrm{F} \cdot \mathrm{g}$ (excluding M.D.). This was lower than the minimum A-a $\mathrm{PO}_{2}$ found in all but one of the perfusion cases. The A-a $\mathrm{PO}_{2}$ breathing $35 \% \mathrm{O}_{2}$ was also of lesser degree in the patients in group II. These results are illustrated in Figs 2 and 3. When the total venous admixture was calculated from this data there was again a striking difference between the two groups (Fig. 4). Ereathing air, five out of the eight patients in group I had a venous admixture effect equivalent to more than $25 \%$ of the cardiac output. In group II, only one patient developed a venous admixture effect of more than $7 \%$. The values for patient M.D. were almost unchanged after operation.

$\mathrm{W}$ hen breathing $100 \% \mathrm{O}_{2}$ (Fig. 5), the differences were equally marked. In group I, every patient except P.H.-R. developed a true shunt of more than $16 \%$ of the cardiac output at some stage of the post- 


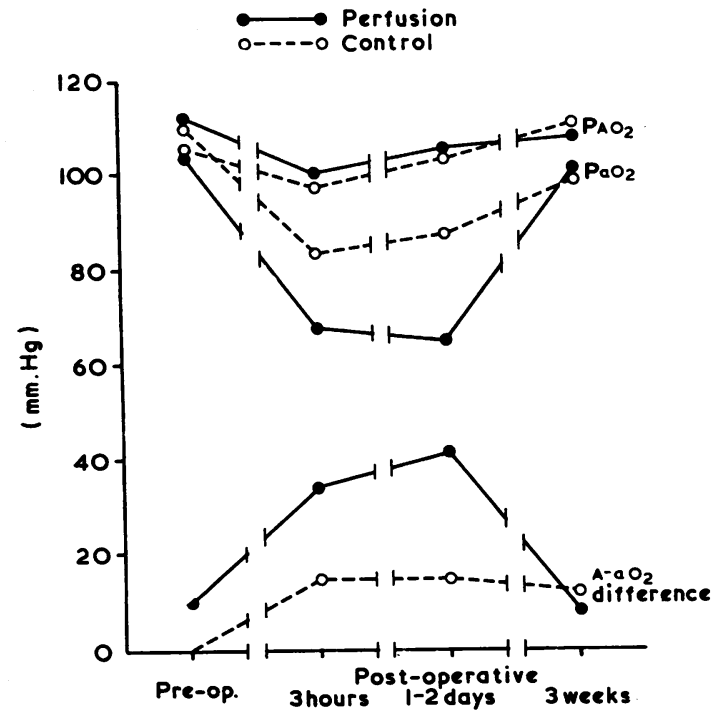

FIG. 2. $\mathrm{PAO}_{2}, \mathrm{PaO}_{2}$, and $\mathrm{A}-\mathrm{a} \mathrm{Po}_{2}$ breathing air.

operative period, whereas in group II only patient M.D. had a true shunt greater than $11 \%$.

In those cases in which measurements were made when breathing $35 \% \mathrm{O}_{2}$, lower values for calculated venous admixture were obtained than on air. In a

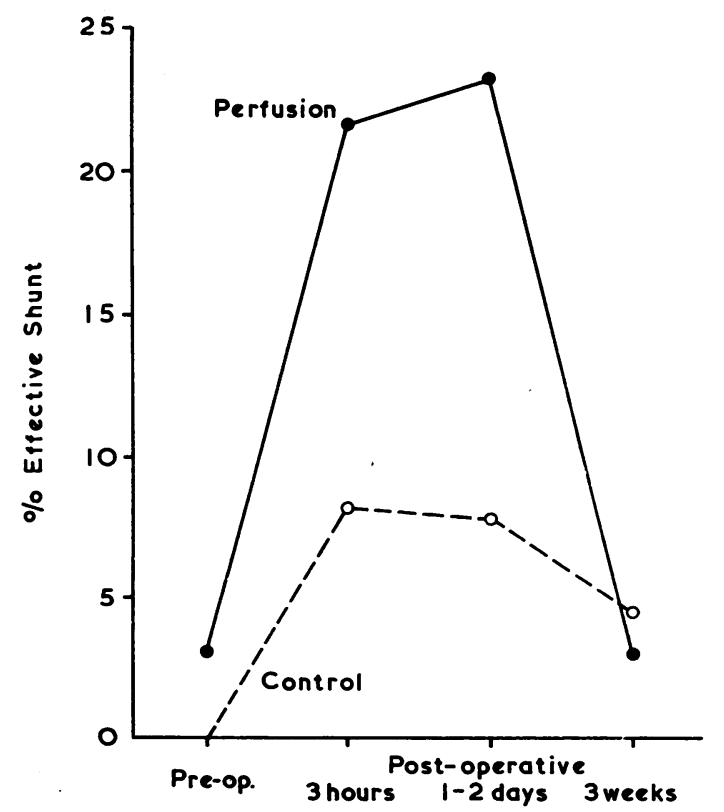

FIG. 4. Percentage shunt breathing air.

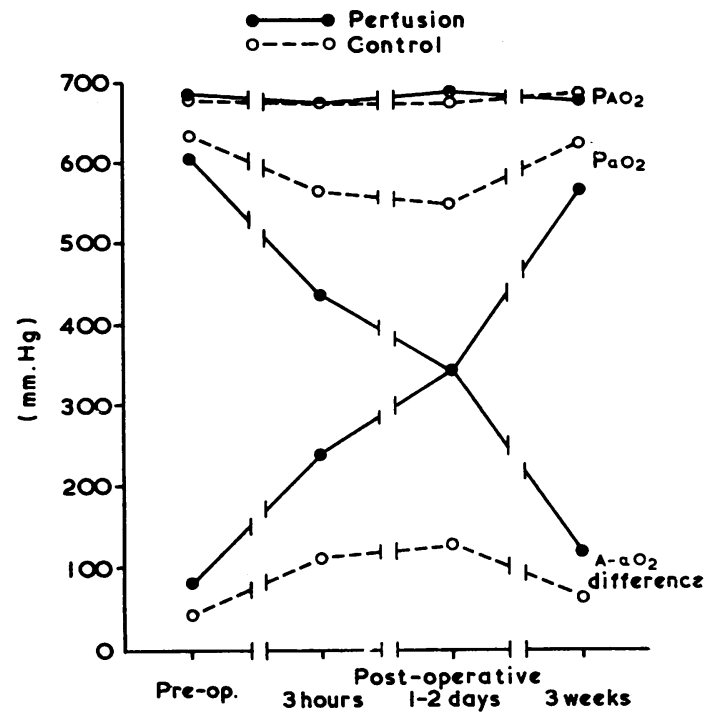

FIG. 3. $\mathrm{PAO}_{2}, \mathrm{PaO}_{2}$, and $\mathrm{A}-\mathrm{a} \mathrm{Po}_{2}$ breathing $100 \% \mathrm{O}_{2}$.

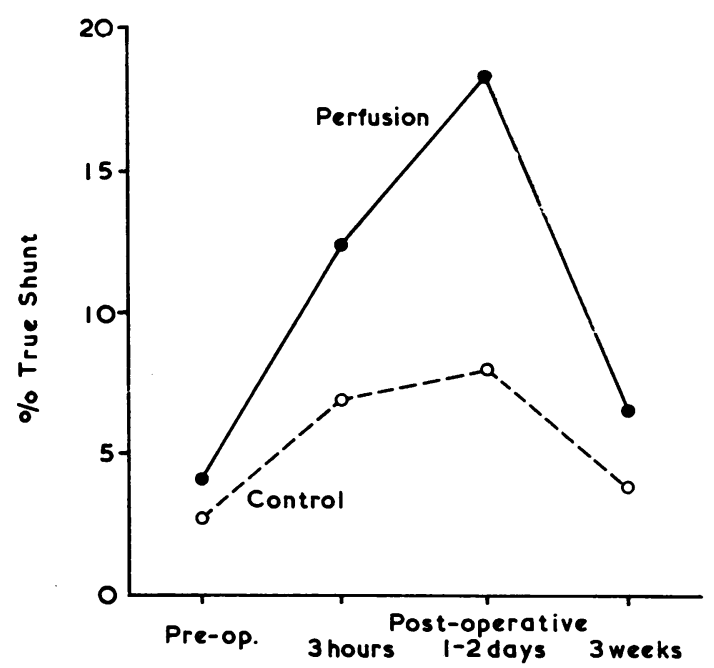

FIG. 5. Percentage shunt breathing $100 \% \mathrm{O}_{2}$.

number of cases the venous admixture was less on $35 \% \mathrm{O}_{2}$ than it was on $100 \% \mathrm{O}_{2}$, but there are too few results to draw any conclusions.

\section{DISCUSSION}

The data show that the majority of patients who undergo cardiac surgery with extracorporeal circulation develop abnormal alveolar-arterial oxygen 
tension differences in the post-operative period. Seven of the eight patients in this group developed an abnormal $\mathrm{A}-\mathrm{a} \mathrm{Po}_{2}$ when breathing air. Only one of the five patients who had thoracic or cardiac surgery without cardiopulmonary bypass, however, developed an A-a $\mathrm{Po}_{2}$ of more than $15 \mathrm{~mm}$. $\mathrm{Hg}$. The sixth patient (M.D.) showed little increase on the pre-operative $\mathrm{A}-\mathrm{a} \mathrm{Po}_{2}$. Another way of expressing this difference between the two groups is to calculate the percentage of venous admixture which would account for the $\mathrm{A}-\mathrm{a} \mathrm{Po}_{2}$ using the equation

$$
\frac{\dot{\mathrm{Q}}_{;}}{\grave{\mathrm{Q}}_{\mathrm{t}}}=\frac{\mathrm{Ca}_{\mathrm{O}_{2}}-\mathrm{Cc}^{\prime} \mathrm{O}_{2}}{\mathrm{C} \overline{\mathrm{V}_{2}} \mathrm{O}_{2}-\mathrm{Cc}^{\prime} \mathrm{O}_{2}}
$$

When using this equation, two assumptions are involved: (1) all sources of venous admixture have the same oxygen tension as the blood in the pulmonary artery, and (2) the volume of the pulmonary artery inflow is equal to the volume of the outflow from the pulmonary veins (Finley et al., 1960). The former would be strictly true only for anatomic shunts through the lungs involving the pulmonary circulation; the latter may be invalidated if blood is added to the pulmonary vein flow from the systemic circulation, e.g., bronchopulmonary flow. Under most conditions these sources of error are small and do not significantly impair the validity of the calculation.

Unless pulmonary artery blood can be sampled directly, the $\mathrm{CV}_{\mathrm{O}} \mathrm{O}_{2}$ can only be estimated. For the shunt calculations quoted in this paper a normal $\mathrm{A}-\mathrm{V}$ difference of 5 vol. $\%$ was used (i.e., $\mathrm{CvoO}_{2}=$ $\mathrm{CaO}_{2}-5$ vol. $\%$ ). The oxygen consumption measurements recorded in this study were within the normal ranges; similar findings have been reported after open-heart surgery by Boyd, Tremblay, Spencer, and Bahnson (1959). These authors also measured cardiac output, using the Fick principle. From their data on a group of patients who underwent openheart surgery it can be calculated that, in 19 patients who had a cardiac index greater than 2 litres per minute and a pulmonary arterial saturation of more than $50 \%$ during the post-operattve period, the average $\mathrm{A}-\mathrm{V}$ difference on the day of operation and for the two days thereafter was $5.3 \mathrm{vol} . \%$ (45 determinations), $5.0 \mathrm{vol} . \%$ (23 determinations), and $5.0 \mathrm{vol} . \%$ (six determinations). The cardiac index in this group ranged from $2 \cdot 3$ to $7 \cdot 4$ litres par minute. All these patients survived the immediate postoperative period. In a second group of 15 patients whose post-operative cardiac indices were less than 2 litres per minute and whose pulmonary arterial saturation fell below $50 \%$ on one or more occasions, the average A-V difference was approximately $8 \mathrm{vol} . \%$; only five of these patients survived the first few days following operation. Clowes, Sabga, Konitaxis, Tomin, Hughes, and Simeone (1961) have also made measurements of cardiac output after open-heart surgery. Using the dye technique, they showed that, if no significant metabolic acidosis was present, cardiac output was generally increased after operation. These authors comment that if the output did not rise after operation the prognosis was usually poor.

Since all cases with a doubtful or poor postoperative cardiovascular status were excluded from the data presented, it appears that the assumption of an $\mathrm{A}-\mathrm{V}$ difference of $\mathrm{S}$ vol.\% for the calculation of shunt was reasonable. Indeed, if the A-V difference had been $8 \mathrm{vol} . \%$ in group I cases and $5 \mathrm{vol} . \%$ in group II cases, the average \% shunt would still have been greater in group I than in group II cases.

By equating the end-capillary oxygen tension with the mean alveolar $\mathrm{Po}_{2}$ all three sources of arterial desaturation, anatomical shunt, distribution, and diffusion are included in the $\mathrm{A}-\mathrm{a} \mathrm{Po}_{2}$ and percentage venous admixture calculated when breathing air. The latter two components are eliminated by breathing $100 \% \mathrm{O}_{2}$; even 35 to $50 \% \mathrm{O}_{2}$ is effective in this regard (Finley et al., 1960; Riley and Cournand, 1951; Riley, Cournand, and Donald, 1951; Asmussen and Nielsen, 1960; Piiper 1961). This

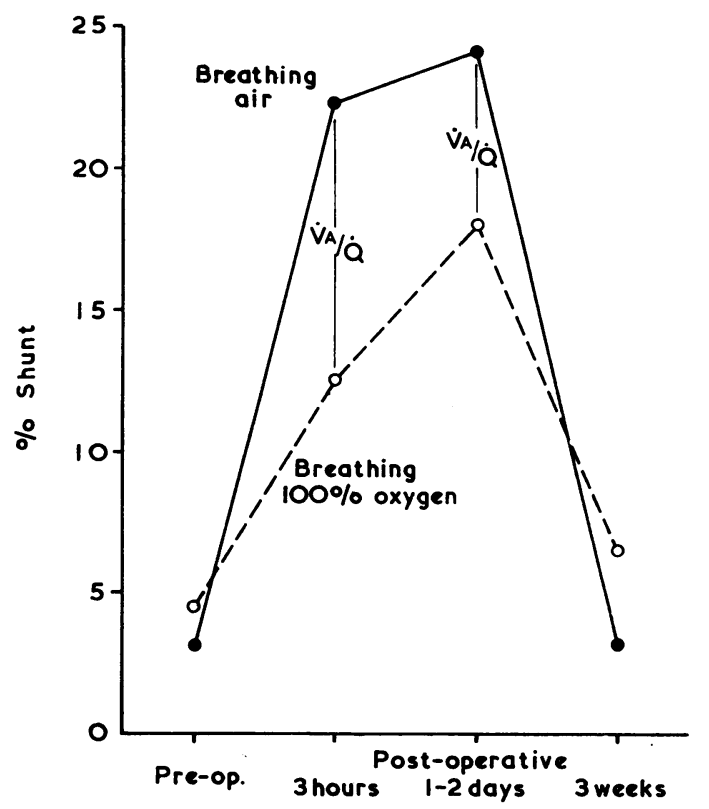

FIG. 6. Anatomical shunt and total venous admixture after total body perfusion. 
is illustrated in Table IV. It may be seen from Tables III and IV and from Figs 4, 5, and 6 that the calculated shunt was reduced in each instance when the patient breathed $100 \% \mathrm{O}_{2}$ : in several cases the percentage venous admixture was reduced by approximately half. This demonstrates clearly the importance of true shunt in the causation of the arterial desaturation noted in this study. The remainder of the desaturation was presumably due to areas of lung where ventilation and perfusion were unequal. Although a number of authors (Schramel et al., 1959; Howatt et al., 1962; Ellison et al., 1963) have demonstrated reductions in diffusing capacity after open-heart surgery, it is likely that the changes noted could be accounted for by the ventilation-perfusion inequalities present.

Although $\mathrm{PaCO}_{2}$ is usually not greatly influenced by uneven ventilation and perfusion (Riley et al., 1951), it should be pointed out that with distribution ( $\left.\dot{V}_{A} / \dot{Q}\right)$ abnormalities of the magnitude encountered in these studies arterial-alveolar gradients for $\mathrm{CO}_{2}$ may be present (Williams and Rayford, 1956). In these circumstances, the measured $\mathrm{PaCO}_{2}$ would be higher than the $\mathrm{PACO}_{2}$ : by equating $\mathrm{PaCO}_{2}$ with $\mathrm{PACO}_{2}$ in the alveolar air equation, a falsely low $\mathrm{PAO}_{2}$ would be calculated. This in turn would lead to an underestimation of the $\mathrm{A}-\mathrm{a} \mathrm{Po}_{2}$ and the magnitude of right to left shunt.

The changes in lung function were observed within a few hours of the conclusion of surgery. Indeed, in a proportion of cases they may be detected within an hour of perfusion (Young, McClenahan, and Sykes, 1965). The changes appear to reach a maximum on the first or second postoperative day and, although measurements were not made from the third post-operative day onward, the clinical condition usually improved rapidly after this time. Three of the four patients in group I tested several weeks after operation showed almost complete resolution of their abnormality. One, who had to be re-operated upon for sternal wound infection, still showed some impairment three weeks after the second procedure, but to a lesser degree. Patient V.P. showed the most striking changes, developing a $46 \%$ shunt on air and a $611 \mathrm{~mm}$. $\mathrm{Hg}$ gradient on $100 \%$ oxygen on the second post-operative day; three weeks after operation there was no measurable abnormality.

In attempting to explain pulmonary complications which follow open-heart surgery with extracorporeal circulation, multiple factors require consideration. Arterial desaturation may be due to hypoventilation or to an increase in the alveolar-arterial oxygen tension difference. Hood and Eeall (1958) have stressed the importance of hypoventilation as a cause of desaturation after thoracic surgery. This cause was excluded in the present series by the normal range of carbon dioxide tensions encountered. Kolff, Effler, Groves, Fughes, and McCormack (1958) suggested that the complications resulted from pulmonary capillary damage initiated by the temporary overloading of the lesser circulation with blood. Eaer and Csborn (1960) pointed out, however, that the syndrome had occurred even when the left atrium was carefully drained. Decreased oxygen saturation has been noted following massive pulmonary embolus in dogs (Stein, Forkner, Robin, and Vessler, 1961). After total unilateral pulmonary artery occlusion shunting was detected when blood flow was restored; this shunting was thought to be secondary to atelectasis which resulted from reflex bronchoconstriction and small airway closure (Severinghaus, Swenson, Finley, Lategola, and X illiams, 1961).

In patients with the tetralogy of Fallot, flow through the enlarged bronchial system, if this persists after complete correction, could account for arterial blood desaturation. If intracardiac defects were not closed or a patent ductus arteriosus remained patent, a shunting of blood right to left through these communications might occur. Differences in the operative technique, such as placement of the incision, the nature of the repair, and the duration of the procedure, may contribute to the genesis of the post-operative abnormalities encountered. An attractive hypothesis is that the desaturation is a consequence of a significant amount of blood shunting through multiple areas of patchy atelectasis which has resulted from an alteration in the surface tension properties of the fluid lining the alveoli. The stability of the alveolar structure depends upon the surface tension of the lining fluid and the modification of these forces by a lipo protein 'surface-active material'. This latter substance tends to lower the surface tension as the alveolus becomes smaller and so prevents its collapse (Pattle, 1958; Clements, 1962). Tooley, Gardner, Thung, and Finley (1961) found that, in dogs which had undergone extracorporeal circulation for one hour, the surface tension of extracts of their lungs was raised within five hours after perfusion. It has also been found that sometimes following bypass a rapid decrease in 'surface-active material' occurs (Clements, 1962). Eaer and Osborn (1960) circulated blood from the carotid to the femoral artery of dogs using a DeBakey pump and a constriction to the outflow tubing to increase turbulence. Several, but not all, of the sacrificed animals showed evidence of congestion, focal collapse, and pulmonary haemorrhage despite the fact that the chest had not been opened. 
Gardner, Finley, and Tooley (1962) added blood which had been pumped through a bubble oxygenator for several hours and normal blood to extracts of dog lung. The surface tension was markedly increased in the pumped blood mixture, whereas that of the non-perfused blood mixture remained normal. This evidence and the findings in this study suggest that the pumping process per se may destroy a blood component or somehow alter its production, which in turn affects the stability of the pulmonary alveolar structure and leads to atelectasis and shunting through the lungs. Further support for this hypothesis has recently been provided by Nahas, Melrose, Sykes, and Robinson (1965a, b).

\section{SUMMARY}

Patients who undergo cardiac surgery with extracorporeal circulation develop significant alveolararterial oxygen tension differences and venous admixture in the early post-operative period. Up to $50 \%$ of this abnormality is due to anatomical right: to left shunting through the lungs; the remainder is most likely to be due to ventilation-perfusion inequâlity. The changes appear to be completely reversible. The cardiopulmonary bypass procedure may be responsible for initiating the underlying pathology, since changes of this magnitude were not found in cardiothoracic surgery patients in whom this technique was not required.

The authors are deeply indebted to Professor J. F. Goodwin, N.r. W. P. Cleland, and Professor H. H. Eentall, who willingly gave us permission to study their patients. They would also like to thank the ward sisters and nursing staff for their co-operation and $\mathrm{N}$. iss Linda Chapman for technical assistance with the blood gas analyses. Research grants were received from the Medical Research Council and the $N$ ational Institutes of Health. The electrode system was purchased with a grant from the National Spastics Society and was kindly loaned by Professor J. P. M. Tizard.

\section{ADDENDUM}

Since this paper was submitted for publication Hedley-Whyte, Corning, Laver, Austen, and Bendixen (1965) have published similar findings.

\section{REFERENCES}

Asmussen, E., and Nielsen, M. (1960). Alveolo-arterial gas exchange at rest and during work at different $\mathrm{O}_{2}$ tensions. Acta physiol. scand., 50, 153.

Astrup. P.. and Schrøder, S. (1956). Apparatus for anaerobic determination of the $p \mathrm{H}$ of the blood at $38^{\circ} \mathrm{C}$. Scand. J. clin. Lab. Invest.. 8, 30 .

Baer, D. M., and Osborn, J. J. (1960). The postperfusion pulmonary congestion syndrome. Amer. J. clin. Path., 34, 442.

Beer, R., Leeschcke, G., Schaudig, A., Pasini, M., Auberger, H. G., Ranz, H., and Borst, H. G. (1961). Lungenfunktion nach Anwendung extrakorporaler Zirkulation. Thoraxchirurgie, 9, 427.
Boyd, A. D., Tremblay, R. E., Spencer, F. C., and Bahnson, H. T. (1959). Estimation of cardiac output soon after intracardiac surgery with cardiopulmonary bypass. Ann. Surg., 150, 613.

Bradley, A. F., Stupfel, M., and Severinghaus, J. W. (1956). Effect of temperature on $\mathrm{PCO}_{2}$ and $\mathrm{PO}_{2}$ of blood in vitro. J. appl. Physiol., $9,201$.

Clements, J. A. (1962). Surface tension in the lungs. Sci. Amer., 207, no. 6, p. 120 .

Clowes, G. H. A., Jr., Sabga, G. A., Konitaxis, A., Tomin, R., Hughes, M., and Simeone, F. A. (1961). Effect of acidosis on cardiovascular function in surgical patients. Ann. Surg., 154, 524.

Comroe, J. H., Jr., Forster, R. E., Dubois, A. B., Briscoe, W. A., and Carlsen, E. (1962a). The Lung, 2nd ed., p. 338. Year Book Publishers, Chicago.

Dodrill - (1962b) Ibid p. 141.

rill, F. D. (1958). The effects of total body perfusion upon the lungs. In Extracorporeal Circulation, p. 32\%, ed. J. G. Allen. Thomas, Springfield, III.

Ellison, L. T., Yeh, T. J., Moretz, W. H., and Ellison, R. G. (1963). Pulmonary diffusion studies in patients undergoing nonthoracic, thoracic, and cardiopulmonary bypass procedures. Ann. Surg., 157, 327.

El Sayed, H., and Melrose, D. G. (1962). Perfusion technique in aortic valve surgery. Lancet, 1, 551

Finley, T. N., Lenfant, C., Haab, P., Piiper, J., and Rahn, H. (1960). Venous admixture in the pulmonary circulation of anesthetized dogs. J. appl. Physiol., 15, 418.

Gardner, R. E., Finley, T. N., and Tooley, W. H. (1962). The effect of cardiopulmonary bypass on surface activity of lung extracts. Bull. Soc. int. Chir., 21, 542 .

Haab, P. E., Piiper, J., and Rahn, H. (1960). Simple method for rapid determination of an $\mathrm{O}_{2}$ dissociation curve of the blood. J. appl. Physiol., 15, 1148.

Hedley-Whyte, J., Corning, H., Laver, M. B., Austen, W. G., and Bendixen, H. H. (1965). Pulmonary ventilation-perfusion relations after heart valve replacement or repair in man. J. clin. Invest. 44, 406.

Hood, R. M., and Beall, A. C. (1958). Hypoventilation, hypoxia, and acidosis occurring in the acute postoperative period. $J$. thorac. Surg., 36, 729

Howatt, W. F., Tainer, N. S., Sloan, H., and DeMuth. G. R. (1962). Pulmonary function changes following repair of heart lesions with the aid of extracorporeal circulation. J. tho: ac. cardiovasc. Surg., 43, 649.

Kolff, W. J., Effier, D. B., Groves, L. K. Hughes, C. R., and McCormack, L. J. (1958). Pulmonary complications of openheart operations: their pathogenesis and avoidance. Cleveland heart operations: their. Quart., 25, 65 .
Clin.

Muller, W. H., Jr., Littlefield, J. B., and Dammann, J. F. (1958). Pulmonary parenchymal changes associated with cardiopulmonary by-pass. In Extracorporeal Circulation, ed. J. G. Allen, p. 336. Thomas, Springfield, Ill.

Nahas, R. A., Melrose, D. G., Sykes, M. K., and Robinson, B. (1965a). Post-perfusion lung syndrome: role of circulatory

scclusion. Lancet, 2, 251. of homologous blood. Ibid., 2, 254.

Osborn, J. J., Popper, R. W., Kerth, W. J., and Gerbode, F. (1962). Respiratory insufficiency following open heart surgery. Ann. Surg., 156, 638.

Pattle, R. E. (1958). Properties, function, and origin of the alveolar lining layer. Proc. Rov. Soc. B, 148, 217.

Piiper, J. (1961). Variations of ventilation and diffusing capacity to perfusion determining the alveolar-arterial $\mathrm{O}_{2}$ difference: theory. J. appl. Physiol., 16, 507.

Riley, R. L., and Cournand, A. (1951). Analysis of factors affecting partial pressures of oxygen and carbon dioxide in gas and blood of lungs: theory. Ibid., 4, 77.

and Donald, K. W. (1951). Analysis of factors affecting partial pressures of oxygen and carbon dioxide in gas and blood partial pressures of oxygen and cart

Schramel, R. J., Cameron, R., Ziskind, M. M., Adam, M., and Creech, O., Jr. (1959). Studies of pulmonary diffusion after open heart surgery. J. thorac. cardiovasc. Surg., 38, 281 .

Severinghaus, J. W., and Bradley, A. F. (1958). Electrodes for blood pO ${ }_{2}$ and $\mathrm{pCO}_{2}$ determination. J. appl. Physiol., 13, 515.

Swenson, E. W., Finley, T. N.. Lategola, M. T., and Williams, J. (1961). Unilateral hypoventilation produced in dogs by occluding one pulmonary artery. Ibid., 16, 53 .

Stein, M., Forkner, C. E., Jr.. Robin, E. D., and Wessler S. (1961). Gas exchange after autologous pulmonary embolism in dogs. Ibid., 16, 488.

Sykes, M. K., McCormick, P. W., Sandison, J., and Harrison, C. G. (1961). Unpublished observations.

Tooley, W., Gardner, R., Thung, N., and Finley, T. (1961). Factors affecting the surface tension of lung extracts. Fed. Proc., 20, 428,

Williams, M. H., and Rayford, C. M. (1956). Effect of variation of tidal volume on size of physiological dead space in dogs. J. appl. Physiol., 9, 30

Young, W. E., McClenahan, J. B., and Sykes, M. K. (1965). Lung function changes after cardiopulmonary bypass. In preparation. 